\title{
O PLANEJAMENTO TRIBUTÁRIO NAS EMPRESAS E OS REQUISITOS UTILIZADOS PELA AUTORIDADE ADMINISTRATIVA PARA A SUA DESCONSIDERAÇÃO
}

\section{THE PLANNING TAX ON BUSINESS AND USED BY THE ADMINISTRATIVE AUTHORITY REQUIREMENTS FOR DISREGARD}

\author{
${ }^{1}$ Demetrius Nichele Macei \\ ${ }^{2}$ Graziela Cristina da Silva Borges Machado
}

\begin{abstract}
RESUMO
O planejamento tributário é um importante instrumento de utilização das empresas com vistas a diminuir, postergar ou eliminar a sua carga tributária. Atualmente, as atividades empresariais são estruturadas, planejadas e organizadas em torno de tributo, visto ser um este um elemento decisivo dentro do seu negócio, todavia, a Administração como não poderia deixar de ser, questiona e averigua se tais procedimentos foram adotados de forma lícita (elisão fiscal) ou ilícita (evasão fiscal), e ainda, que verificado a licitude, procuram averiguar seus propósitos. Diante de tal relação, importante análise deve ser empreendia para verificar quais são os limites adotados pelo físco, dentro do procedimento ou do processo administrativo que lhe é inerente, para a desconsideração de tais atos.
\end{abstract}

Palavras-chave: Planejamento tributário, Elisão, Evasão, Simulação, Dissimulação

\begin{abstract}
Tax planning is an important instrument for the use of company in order to reduce, delay or eliminate their tax burden. Actually, the business activities are structured, planned and organized around tax, since this is a decisive element within your business, however, the Administration as it should not be, questions and examines whether such procedures were adopted lawfully (tax avoidance) or illegal (tax evasion), and yet, who checked the legality, seek to ascertain its purpose. Faced with such respect, important analysis should be waged to see which are the limits adopted by the tax authorities, within the procedure or the administrative process that is inherent to the disregard of such acts.
\end{abstract}

Keywords: Planning tax, Tax avoidance, Tax evasion, Simulation, Dissimulation

\footnotetext{
${ }^{1}$ Professor de Direito Tributário na graduação, especialização e mestrado na Faculdade de Direito Curitiba, UNICURITIBA Curitiba - PR, (Brasil). E-mail: demetriusmacei@gmail.com

${ }^{2}$ Professora de Planejamento Tributário ICMS/IPI/ISS na pós graduação em Gestão Tributária, FESP - Paraná - PR,

(Brasil). E-mail: grazielasilva.machado@gmail.com
} 


\section{INTRODUÇÃO}

A relação entre a Administração Pública e o Contribuinte, em especial no campo tributário, sempre foi tênue. Isso ocorre porque, de um lado o Estado necessita e quer arrecadar, do outro, o contribuinte, que até quer pagar, entretanto, entendendo que a carga tributária é elevada e por isso prejudica o seu negócio, procura mecanismos para diminuí-la.

Segundo dados obtidos da Receita Federal do Brasil (BRASIL, 2013, p. 1), em 2013 a Carga Tributária Bruta $^{1}$ representou 35,95\% do Produto Interno Bruto. Esse percentual aumenta a cada ano, o que é bom para Estado, mas ruim para o contribuinte que não consegue se conformar, em haver uma arrecadação tal alta, para uma contrapartida tal baixa.

Em virtude dessa disparidade (entre o arrecadado e o aplicado pelo Estado), que não faz sentido para o contribuinte, é que este procura adotar mecanismos que venham a reduzir ou até mesmo eliminar a sua carga tributária. Quando adotada de forma lícita, tal conduta é normalmente denominada de "planejamento tributário".

Ao envolver a adoção de condutas que venham a postergar, diminuir ou excluir o tributo, o tema do planejamento tributário, alcança um papel relevante não só na relação entre o fisco e o contribuinte, como para toda a sociedade, que em última análise, é a destinatária dos efeitos dessa relação.

Assim, o artigo ora proposto, tem por objetivo geral investigar quais são os fundamentos utilizados pela Administração para a desconsideração de planejamentos tributários.

Em relação ao objetivo específico, procurar-se-á verificar os diversos conceitos que norteiam o procedimento e o processo administrativo, bem como o planejamento tributário.

A partir dos objetivos ora propostos, têm o presente artigo por escopo, averiguar em que medida o planejamento tributário adotado pelas empresas com o intuito de diminuir os seus tributos pode ser desconsiderado no procedimento administrativo.

Tal averiguação é relevante, na medida em que sabemos que a função do fisco é arrecadar e a do contribuinte recolher os tributos devidos, entretanto, entre o arrecadar e o recolher existe um espaço de condutas praticadas tanto pelo sujeito ativo, quanto pelo sujeito passivo que merecem ser analisadas.

\footnotetext{
1 "A Carga Tributária Bruta é definida como a razão entre a arrecadação de tributos e o PIB a preços de mercado, ambos considerados em termos nominais". Disponíve em <http://idg.receita.fazenda.gov.br/dados/receitadata/estudos-e-tributarios-e-aduaneiros/estudos-eestatisticas/carga-tributaria-no-brasil/carga-tributaria-2013.pdf $>$ Acesso em 02/08/15 às 20:00 hs.
} 


\section{PROCEDIMENTO OU PROCESSO ADMINISTRATIVO TRIBUTÁRIO}

\subsection{Conceito}

Mello (2009, p. 480) define o procedimento ou processo administrativo como "uma sucessão itinerária e encadeada de atos administrativos que tendem, todos, a um resultado final e conclusivo", ou seja, refere-se a uma sequência de atos praticados pela autoridade administrativa com o objetivo de alcançar uma decisão final e legal sobre determinado assunto.

Não há uma normal geral de direito tributário que disponha sobre o processo administrativo, sendo este regulado no âmbito federal pelo Decreto $n^{\circ} 70.235 / 72^{2}$ e pela Lei $n^{\circ}$ $9.784 / 99^{3}$. No âmbito estadual e municipal, cabe a cada ente regulamentar o seu processo administrativo. (Paulsen, 2014, p. 403-404)

Também se faz necessário destacar a utilização do termo "procedimento/processo", pois, vamos nos deparar com ambas as expressões. A Lei Federal $n^{\circ}$ 9.784, de 24 de janeiro de 1999 (BRASIL, 1999), que trata sobre o assunto, traz como ementa "Regula o processo (grifo nosso) administrativo no âmbito da Administração Pública Federal”, logo se observa, que este importante diploma legal utiliza o termo "processo" e não "procedimento",

Mello (2009, p. 481) ao analisar a utilização das referidas terminologias observa que: "Não há negar que a nomenclatura mais comum no Direito Administrativo é procedimento, expressão que se consagrou entre nós, reservando-se, no Brasil, o nome juris processo para os casos contenciosos", embora entenda o autor (2009, p. 481) que a terminologia mais adequada seja processo, designando como procedimento: "a modalidade ritual de cada processo"; todavia, deixa claro que (2009, p. 481): "Não é o caso de armar-se um 'cavalo de batalha' em torno de rótulos", optando por utilizar ambos os termos.

No campo tributário, importante lição nos é passada por Marins (2010, p. 146), que ao analisar as diferenças entre processo e procedimento assim dispõe: "transmuda-se a atividade administrativa de procedimento para processo no momento em que o contribuinte registra seu inconformismo com o ato praticado pela Administração"; assim, a diferença entre o procedimento e o processo no campo tributário, para o referido autor, consistirá na resistência do contribuinte, da sua não aceitação da imposição realizada pelo fisco, que normalmente se dá pelo lançamento do tributo devido exigido por meio do Auto de Infração;

\footnotetext{
${ }^{2}$ Dispõe sobre o processo administrativo fiscal, e dá outras providências.

${ }^{3}$ Regula o processo administrativo no âmbito da Administração Pública Federal
} 
mas que pode comportar outros atos que culminem na exigência de penalidades, como por exemplo, a não entrega de uma declaração, a falta de informações nos documentos fiscais, entre outros.

Adotando-se a diferença suscitada por Marins, pode-se dizer que o processo administrativo pode iniciar-se de ofício ou a pedido de interessado, por isso, a Administração tem de ser provocada ou então agir de ofício nas situações legalmente previstas.

Seja por provocação, seja por ofício o processo administrativo se formará a partir de documentações, análises técnicas e demais atos previstos, com vistas a apurar os fatos e chegar a um resultado final, por isso, dispõe Mello (2009, p. 484) que: "É esta totalidade que servirá como aval do ato ou - pelo contrário - que permitirá exibir seu descabimento”.

Também destaca Mello (2009, p. 484) que: “é necessário saber-se como e por quê o administrador chegou à conclusão traduzida no ato", eis que (2009, p. 483):

\footnotetext{
"no Estado de Direito os cidadãos têm a garantia não só de que o Poder Público estará, de antemão, cifrado unicamente à busca dos fins estabelecidos em lei, mas também de que tais fins só poderão ser perseguidos pelo modos adrede estabelecidos para tanto".
}

Assim, o Poder Púbico esta adstrito aos limites da lei, todavia há que se observar, que a atividade administrativa pode ser vinculada ou discricionária.

Para Di Pietro (2001, p. 66) a atividade administrativa é vinculada: "porque a lei não deixa opções; ela estabelece que, diante de determinados pressupostos, a Administração deve agir de tal ou qual forma”, em contrapartida, a atividade discricionária é assim denominada segundo a mesma autora (2001, p. 66): “porque a adoção de uma ou outra solução é baseada em critérios de mérito - oportunidade, conveniência, justiça, igualdade, a serem perquiridos pela autoridade, porque não definidos pelo legislador".

A separação entre atividade "discricionária" e atividade "vinculada" é importante para que o contribuinte saiba em que medida pode exigir da Administração Pública determinadas condutas; assim, diante de um ato vinculado, como por exemplo, a concessão de "Certidão Negativa de Débitos" ou a liberação de "Notas Fiscais", deve a empresa acionar judicialmente a Administração, caso este não expeça o referido documento.

$\mathrm{Na}$ atividade discricionária temos um campo de maior liberdade para o poder público, como por exemplo, na concessão de regimes especiais ou tratamentos tributárias diferenciados conferidos à algumas empresas, entretanto, conforme observa Di Pietro (2001, p. 67): "embora discricionário, não é totalmente livre, porque, sob alguns aspectos, em especial a competência, a forma e a finalidade, a lei impões limitações”. 
Importante ressaltar que tanto no processo, quanto no procedimento há princípios norteadores da sua aplicação.

\subsection{Princípios do Procedimento e do Processo Administrativo}

Conforme define Junior (1988, p. 7): "Princípio de uma ciência são as proposições básicas, fundamentais, típicas, que condicionam todas as estruturações subsequentes. Princípio, nesse sentido, são os alicerces, os fundamentos da ciência”; nessa mesma esteira Carvalho (2009, p. 163) define os princípios: "como linhas diretivas que iluminam a compreensão de setores normativos, imprimindo-lhes caráter de unidade relativa e servindo de fator de agregação num dado feixe de normas".

Ainda que não haja uma norma geral sobre os princípios aplicáveis ao procedimento e ao processo administrativo, a Lei $\mathrm{n}^{\circ}$ 9.784/99 (BRASIL, 1999) que regula o processo administrativo no âmbito da administração pública federal destaca em seu artigo $2^{\circ}$ que será observado, dentre outros, os seguintes princípios: "legalidade, finalidade, motivação, razoabilidade, proporcionalidade, moralidade, ampla defesa, contraditório, segurança jurídica, interesse público e eficiência".

Na Constituição de 1988 (BRASIL, 1988) também é assegurado a todo cidadão, o contraditório e a ampla defesa, tanto no processo judicial, quanto no âmbito administrativo (art. $\left.5^{\circ}, \mathrm{LV}\right)$, constituindo tais princípios instrumentos de proteção contra eventuais arbitrariedades do Estado, bem como a defesa e a análise de entendimentos contrários por parte dos administrados.

O caput do art. 37 da Constituição Federal (BRASIL, 1988), é um dos mais referenciados pela doutrina porque expressamente referência os princípios da administração pública: legalidade, impessoalidade, moralidade, publicidade e eficiência.

Marins (2010, p. 150) ao analisar a doutrina tributária e administrativa, identificou 51 princípios aplicáveis ao procedimento e ao processo administrativo, dispondo (2010, 151): “O elevado número de princípios dificulta a lapidação do sistema procedimento-processo administrativo, sobretudo tendo-se em conta o fato de que, em geral, o elenco de princípios feito pela doutrina não observa a necessária diferença entre procedimento e processo", eis ai, a dificuldade em distinguir um e outro (processo e procedimento) e os princípios aplicáveis a cada um deles ou a ambos, conforme o caso. 
Para tratarmos sobre os princípios aplicáveis ao procedimento e ao processo administrativo tributário utilizaremos a classificação realizada por Marins que os divide em "Princípios Constitucionais Gerais da Administração Pública", em especial no art. 37 da Constituição: legalidade, finalidade, razoabilidade, proporcionalidade, motivação, impessoalidade, publicidade, moralidade, responsabilidade e eficiência; "Princípios comuns ao Procedimento e ao Processo": legalidade objetiva, vinculação, verdade material, oficialidade, dever de colaboração e dever de investigação; "Princípios do Procedimento Administrativo Fiscal": inquisitoriedade, cientificação, formalismo moderado, fundamentação, acessibilidade, celeridade e gratuidade e "Princípio do Processo Administrativo Tributário: devido processo legal, contraditório, ampla defesa, ampla instrução probatória, duplo grau de cognição, julgador competente, ampla competência decisória e razoável duração do processo. (Marins, 2010, p. 154) O art. $3^{\circ}$. do Código Tributário Nacional (BRASIL, 1966) determina que o tributo $^{4}$ é instituído por lei e cobrado mediante atividade administrativa plenamente vinculada, o que significa dizer que não há espaço para invocar critérios de oportunidade e conveniência, devendo-se observar o princípio da legalidade objetiva, que nos dizeres de Marins (2010, p.156)

\begin{abstract}
"é o corolário do princípio da autotutela vinculada da Administração tributária, o que significa dizer que embora o Estado tenha a prerrogativa de promover todas as providências necessárias para a formalização da sua relação de crédito em face do contribuinte, somente pode fazê-lo com adstrição à norma jurídica que disciplina e instrumentaliza sua atuação."
\end{abstract}

Assim, o princípio da legalidade objetiva, que norteia tanto o processo quanto o procedimento administrativo tributário, visa assegurar que as atividades desenvolvidas para constituição do crédito tributário são adotadas nos termos da lei, não permitindo nenhum grau de liberdade ou favoritismo por parte do agente administrativo, que deve agir de forma imparcial e impessoal.

O princípio da vinculação decorre do princípio da legalidade objetiva, e tem por objetivo enquadrar/tipificar o comportamento da Administração, o que nos dizeres de Marins (2010. p. 157) "condiciona o atuar administrativo-fical, isto é, o modo como deve reger-se a Administração em sua tarefa de fiscalização, apuração e cobrança do crédito tributário", que sempre estará vinculada ao comando disciplinado na norma.

\footnotetext{
${ }^{4}$ Art. $3^{\circ}$ Tributo é toda prestação pecuniária compulsória, em moeda ou cujo valor nela se possa exprimir, que não constitua
} 
O princípio da oficialidade refere-se a impulsão dos atos, conforme observa Mello (2009, p. 497): “é encargo da própria Administração; vale dizer, cabe a ela, e não a um terceiro, a impulsão de ofício, ou seja, o empenho na condução e desdobramento da sequência de atos que o compõem até a produção do ato final, conclusivo".

O princípio da verdade material é de grande relevância, pois, tem como objetivo aproximar a Administração da realidade de fato por meio de diligências, análise mais detalhada das operações, e com isso evitar arbitramentos, que normalmente decorrem da falta de interesse do agente em buscar a verdade material, ou até mesmo de enxergá-la. (Marins, 2010, p. 158).

Merece ainda destacar, em relação ao princípio da verdade material, a observação feita por Macei (2013, p. 177):

“A busca pela verdade material é princípio de observância indeclinável da Administração Tributária no âmbito de suas atividades procedimentais e processuais. Ela deve fiscalizar em busca da verdade; deve apurar e lançar com base na verdade; deve julgar com base na verdade."

O princípio do dever de investigar está insculpido nos arts. 194 a 200 do Código Tributário Nacional (BRASIL, 1966) que tratam sobre as normas de fiscalização a serem observadas pelas autoridades administrativas, todavia, conforme observa Marins (2010, p.

160): “o plexo de poderes de investigação não é, contudo, ilimitado, pois, encontra barreiras no campo das garantias individuais do cidadão, como aquelas previstas no art. $5^{\circ}$ da Constituição", por isso, o dever de investigar que é fundamental para que se apure os fatos, não deve violar direitos importantes dos cidadãos, como a intimidade e a privacidade.

Assim como o "princípio do dever de investigar" está voltado à Administração, o “princípio do dever de colaborar", está voltado para o cidadão-contribuinte, que deve contribuir para o bom andamento das averiguações ou investigações; assim, deve colaborar entregando livros e demais documentos necessários para averiguação da correta exigência do crédito tributário. Tal conduta contribui para se alcançar, em última instância, a verdade material. (Marins, 2010, p. 160-161).

Entretanto, em relação ao dever de colaboração importante observação é feita por Marins (2010, p. 161): "Não estão os particulares, empresas ou instituições, obrigados a colaborar quando estiver em jogo a inviolabilidade da intimidade e da vida privada", assim como o dever de investigar possui limites, o de colaborar também. 
Feita uma breve explanação dos princípios que norteiam tanto o processo, quanto o procedimento administrativo tributário/fiscal, passa-se a analisar, os princípios inerentes ao procedimento e, na sequência, os princípios relativos ao processo administrativo fiscal.

Os princípios aplicáveis ao procedimento administrativo, nos dizeres de Marins (2010, p. 161): “formam a base lógica para a compreensão do regime jurídico procedimental tributário". Como princípios do procedimento administrativo, seguindo a classificação feita por Marins, têm-se: inquisitoriedade, cientificação, formalismo moderado, fundamentação, acessibilidade, celeridade e gratuidade.

O princípio da inquisitoriedade não se confunde com arbitrariedade ou discricionariedade, mas sim, com averiguação e preparação. Refere-se nos dizeres de Marins (2010, p. 161-162): "da relativa liberdade que se concede à autoridade tributária em sua tarefa de fiscalização e apuração dos eventos de interesse tributário".

O art. 3º, II, da Lei $n^{\circ}$ 9.784/99 (BRASIL, 1999), Lei do Processo Administrativo Fiscal determina que "o administrado deve ter ciência da tramitação dos processos administrativos em que tenha a condição de interessado", logo, o princípio da cientificação corresponde ao direito de comunicação ao cidadão-contribuinte de atos em que figure como parte. Também determina o art. $7^{\circ}$, I, do Decreto $n^{\circ} 70.235 / 72$ (BRASIL, 1972) que "o procedimento fiscal tem início com o primeiro ato de ofício, escrito, praticado por servidor competente, cientificado (grifo nosso) o sujeito passivo da obrigação tributária ou seu preposto".

O princípio da acessibilidade dos autos nos dizeres de Mello (2009, p. 495): "significa que à parte deve ser facultado o exame de toda a documentação constante dos autos", ou seja, que ao cidadão-contribuinte seja garantido o acesso a todos os autos que seja parte interessada.

O princípio do formalismo moderado, refere-se a adoção de atos mais simples na relação entre a Administração e o administrado, visa, evitar que os atos contenham exageros ou formas rebuscadas, ritos e solenidades desnecessárias que em nada contribuem para a compreensão do cidadão-contribuinte. (Marins, 2010, p. 164-165).

O princípio da fundamentação é um dos mais importantes dentro do procedimento administrativo, pois, segundo Marins (2010, p. 165): "Fundamentar o ato ou a decisão administrativa significa declarar expressamente a norma legal e o acontecimento fático que autoriza a prática do ato ou a prolação da decisão". É por meio da fundamentação exposta pela autoridade administrativa que o administrado terá condições de se manifestar favorável ou não a decisão; de se defender, por isso, a fundamentação deve ser simples, clara e objetiva. 
O princípio da celeridade visa evitar que os procedimentos sejam praticados de forma lenta e desgastante, gerando atrito entre a Administração e o administrado, nesse sentindo leciona Marins (2010, p. 166): “A morosidade é cara e lesiva, é social e economicamente indesejável: procedimento administrativo bom é aquele que evita o desgaste entre Fisco e contribuinte", todavia, alerta o autor (2010, p. 167) que a celeridade "que vigora no procedimento administrativo não pode ser aplicado pura e simplesmente no processo administrativo, sob pena de afronta a outros princípios constitucionais, tais como o da ampla defesa e o da segurança jurídica".

Para finalizar os princípios norteadores do processo administrativo temos o princípio da gratuidade disposto no art. $2^{\circ}$, XI, da Lei n 9.784/99 (BRASIL, 1999) que proíbe "a cobrança de despesas processuais, ressalvadas as previstas em lei”.

Conforme mencionado no tópico 1.1, o processo administrativo tem início com a impugnação apresentada pelo contribuinte, ou seja, com a sua não concordância em relação a exigência do crédito tributário.

Os princípios guias do processo administrativo, dando sequência na classificação adotada por Marins, são: do devido processo legal, contraditório, ampla defesa, ampla instrução probatória, duplo grau de cognição, julgador competente, ampla competência decisória e razoável duração do processo.

O devido processo legal previsto no art. $5^{\circ}$, LIV $^{5}$, da Constituição Federal determina nos dizeres de Mello (2009, p. 115) que: “a Administração Pública não poderá proceder contra alguém passando diretamente a decisão que repute cabível, pois terá, desde logo, o dever jurídico de atender ao contido nos mencionados versículos constitucionais", por isso, exigir-se-á da Administração que observe criteriosamente as formalidades do processo, a fim de permitir ao contribuinte a ampla defesa e o contraditório.

O princípio do contraditório e da ampla defesa também estão previstos no texto constitucional (art. $\left.5^{\circ}, \mathrm{LV}\right)^{6}$ e refere-se ao direito do contribuinte de se manifestar de maneira contrária a imposição do Estado; no campo tributário, se refere a impugnação, onde o administrado tem a oportunidade de se manifestar sobre cada ponto arguido pelo fisco na autuação.

\footnotetext{
${ }^{5}$ LIV - ninguém será privado da liberdade ou de seus bens sem o devido processo legal.

${ }^{6} \mathrm{LV}$ - aos litigantes, em processo judicial ou administrativo, e aos acusados em geral são assegurados o contraditório e ampla defesa, com os meios e recursos a ela inerentes;
} 
O princípio da ampla competência decisória refere-se a exigência de apreciação pelo órgão julgador de toda matéria de defesa trazida pelo contribuinte, pois, conforme destaca Marins (2010, p. 172): “quer se tratem de questões concernentes à mera irregularidade formal do auto de infração, quer se trate de alegação de ilegalidade ou inconstitucionalidade de norma jurídica tributária, toda matéria de defesa deve ser formalmente apreciada".

O princípio da ampla instrução probatória relaciona-se com a produção de provas dentro do processo administrativo, ou seja, tem como objetivo a apreciação de provas pelo julgador. Tais provas podem decorrer da elaboração de laudos técnicos, documentação, pareceres com explicação detalhadas da operação, entre outras, desde que não ilícitas, que têm como objetivo auxiliar a decisão do órgão julgador. (Marins, 2010, p. 173)

O princípio do duplo grau de cognição, refere-se a possibilidade dada ao contribuinte de recorrer da decisão dada num primeiro julgamento; significa que o contribuinte poderá apresentar recurso caso a sua impugnação não tenho sido acatada ou acatada parcialmente. (Marins, 2010, p. 174-175)

Para Marins (2010, p. 175) o princípio do julgador competente determina que: “Tais órgãos devem ser dotados de julgadores administrativos imparciais, competência julgadora previamente estabelecida na legislação e adequados mecanismos prévios de determinação de competência para cada caso concreto que lhes for submetido à apreciação", com isso, busca-se a imparcialidade dos julgamentos, que é fundamental para a apreciação da lide sem favoritismos ou preferências.

O último princípio a ser analisado dentro do processo administrativo tributário, dentro da linha adotada para esse tópico (classificação realizada por Marins), tem-se o princípio da razoável duração do processo administrativo, que não significa rapidez, o que poderia inclusive prejudicar a análise dos fatos pelo órgão julgador, nem lentidão, que tornaria o processo moroso e talvez ineficaz para o fim proposto. (Marins, 2010, p. 176-177).

No âmbito tributário, os princípios acima citados, são fundamentais para garantir que o procedimento e o processo administrativo fiscal possam transcorrer de maneira satisfatória tanto para a Administração, quanto para os administrados, entretanto, o que se vê na prática tributária são atos arbitrários por parte da administração pública, devido ao seu agigantamento frente ao contribuinte, e ao seu poder de constituir o crédito tributário por meio do lançamento, por isso, a análise dos aspectos que envolvem o lançamento são de suma importância para averiguar a sua exigência.

Revista de Direito Tributário e Financeiro | e-ISSN: 2526-0138 | Minas Gerais | v. 1 | n. 2 | p. 394 - 419 | Jul/Dez. 2015. 
O tributo representa interferência do Estado no patrimônio dos administrados; assim compete privativamente a autoridade administrativa exigir o crédito tributário por meio do lançamento.

\subsection{O Lançamento Como Ato ou Procedimento Administrativo}

O art. 142, do Código Tributário Nacional (BRASIL, 1966), denominado simplesmente de CTN, define o lançamento como procedimento administrativo:

\footnotetext{
"Compete privativamente à autoridade administrativa constituir o crédito tributário pelo lançamento, assim entendido o procedimento administrativo (grifo nosso) tendente a verificar a ocorrência do fato gerador da obrigação correspondente, determinar a matéria tributável, calcular o montante do tributo devido, identificar o sujeito passivo e, sendo caso, propor a aplicação da penalidade cabível.

Parágrafo único. A atividade administrativa de lançamento é vinculada e obrigatória, sob pena de responsabilidade funcional."
}

Logo, pela definição constante no CTN, o tributo é constituído pelo lançamento, todavia, os estudos mais apurados sobre o tema analisam o conceito constante no art. 142 que define o lançamento como "procedimento administrativo".

Carvalho (2009, p. 426) em minuncioso estudo sobre o lançamento, assim o definiu:

"Lançamento tributário é ato jurídico administrativo, de categoria dos
simples, constitutivos e vinculados, mediante o qual se insere na ordem jurídica
brasileira u'a norma individual e concreta, que tem como antecedente o fato
jurídico tributário e, como consequente, a formalização do vínculo obrigacional,
pela individualização dos sujeitos ativo e passivo, a determinação do objeto da
prestação, formado pela base de cálculo e correspondente alíquota, bem como
pelo estabelecimento dos termos espaço-temporais em que o crédito há de ser
exigido."

O conceito exposto por Carvalho define o lançamento como um "ato jurídico administrativo" e não como "procedimento administrativo". Marins (2010, p. 183) ao analisar o assunto dispôs que: "Nem sempre o ato de lançamento será precedido de procedimento, pois, há casos em que a autoridade administrativa serve-se de elementos pré-fixados que dispensam procedimento próprio para a individualização da obrigação tributária”.

Assim o lançamento que visa constituir o crédito tributário, nem sempre conterá procedimentos preparatórios, tais como: diligências, verificação de documentos e mercadorias, para a sua exigência; tal situação ocorre com o IPTU - Imposto sobre Propriedade 
Territorial Urbana e com o IPVA - Imposto sobre Propriedade de Veículo Automotor. Para o lançamento dos referidos impostos não é necessário que o agente administrativo efetue diligências ou análise de documentos, a fim de constituir o crédito tributário, bastando apenas aplicar a alíquota sobre a base de cálculo que é aferida no caso do IPVA, com base em tabela de preços médios de veículos, elaborada pela Fundação Instituto de Pesquisas Econômicas - FIPE e no caso do IPTU, em planta de valores. (Marins, 2010, p.183).

Para Machado, não há relevância em discutir se o lançamento é um "ato" ou um "procedimento", pois, o art.142 do CTN, ora quis se referir a um conceito, ora a outro. (Machado, 2010, p. 51). Entretanto, destaca o autor que (2014, p. 51) que: "o lançamento administrativo é, na verdade, um procedimento, no sentido de atividade que, por afetar direitos dos administrados, há de ser desenvolvida com obediência a certas formalidades legalmente impostas", tais conclusões se dão pela análise de que sempre haverá pelo menos mais um ato a ser realizado pela autoridade administrativa.

Para exemplificar pensemos nos impostos citados acima: o IPVA e o IPTU. Ainda que o lançamento não careça de outros dados que não a verificação dos valores e das alíquotas realizadas pela própria administração, ou seja, sem a participação do contribuinte; ainda sim, têm-se a notificação do lançamento junto ao contribuinte para que tome ciência do valor a recolher; além disso, sempre é possível que o contribuinte queira questionar, é o seu direito de se defender assegurado constitucionalmente, e nessa situação, uma série de procedimentos devem ser observados. (Machado, 2010, p. 51-52).

Realizadas análises pontuais sobre o lançamento, seja como ato, seja como procedimento administrativo, passa-se a averiguar em que medida o contribuinte pode adotar condutas que visem diminuir o tributo, que é exigido pelo lançamento. 


\section{O PLANEJAMENTO TRIBUTÁRIO}

\subsection{Alguns Conceitos Importantes}

Antes de se analisar as diversas definições utilizadas pela doutrina com o intuito de definir "planejamento tributário", pretende-se averiguar alguns conceitos (e não todos, por depender de um tempo de pesquisa mais apurado) bases relacionados ao tema do planejamento tributário.

O primeiro conceito a ser analisado é o da "simulação", cuja definição consta no art. 167 do Código Civil (BRASIL, 2002):

\footnotetext{
“Art. 167. É nulo o negócio jurídico simulado, mas subsistirá o que se dissimulou, se válido for na substância e na forma."

\$ $1^{\text {O }}$ Haverá simulação nos negócios jurídicos quando: (grifo nosso)

I - aparentarem conferir ou transmitir direitos a pessoas diversas daquelas às quais realmente se conferem, ou transmitem;

II - contiverem declaração, confissão, condição ou cláusula não verdadeira; III - os instrumentos particulares forem antedatados, ou pós-datados."
}

Analisando a figura da simulação no campo tributário Greco (2011, p. 276) assim a define: "nela, há um negócio jurídico aparente, celebrado entre as partes, ao mesmo tempo em que há um segundo negócio jurídico, este real e querido pelas partes, mas que não resulta visível”, assim na simulação há a intenção de disfarçar os reais motivos do negócio jurídico praticado, de enganar terceiros; que para o campo que nos propusemos a analisar, será o físco.

Entretanto, a afirmação de que o negócio jurídico é simulado, deve ser visto com cautela, caso a caso, pois, além de se averiguar se existe mais de uma vontade (aparente e real), é importante averiguar se o motivo "desejado/querido" corresponde ou não ao motivo “exposto/relatado". (Greco, 2011, p. 277)

A Lei $n^{\circ} 4.502$, de 30 de novembro de 1964 (BRASIL, 1964) foi recepcionada pela Constituição Federal como Lei Ordinária a dispor sobre o IPI - Imposto sobre Produtos Industrializados. Na referida Lei encontramos os arts. $71^{7}, 72^{8}$ e $73^{9}$ que respectivamente definem sonegação, fraude e conluio.

\footnotetext{
7 Art . 71. Sonegação é toda ação ou omissão dolosa tendente a impedir ou retardar, total ou parcialmente, o conhecimento por parte da autoridade fazendária:

I - da ocorrência do fato gerador da obrigação tributária principal, sua natureza ou circunstâncias materiais;

II - das condições pessoais de contribuinte, suscetíveis de afetar a obrigação tributária principal ou o crédito tributário correspondente.

8 Art . 72. Fraude é toda ação ou omissão dolosa tendente a impedir ou retardar, total ou parcialmente, a ocorrência do fato gerador da obrigação tributária principal, ou a excluir ou modificar as suas características essenciais, de modo a reduzir o montante do imposto devido a evitar ou diferir o seu pagamento.

9 Art . 73. Conluio é o ajuste doloso entre duas ou mais pessoas naturais ou jurídicas, visando qualquer dos efeitos referidos nos arts. $71 \mathrm{e}$ 72.
} 
O conluio caracteriza-se pelo acordo doloso com duas ou mais pessoas para a prática da sonegação ou da fraude.

Em relação a sonegação, importante observação é feita por Greco (2011, p. 266): "só tem cabimento se houver conduta que implique impedir ou retardar o conhecimento pela autoridade fazendária, de qualquer procedimento ligado ao fato gerador da obrigação tributária ou das condições pessoais do contribuinte"; exemplo clássico de sonegação, é a não emissão de nota fiscal pelas empresas revendedoras, pois, não emitindo o documento fiscal, o contribuinte impede o conhecimento por parte da autoridade fazendária da ocorrência do fato gerador dos tributos devidos.

A fraude, constante no art. 72 da Lei n ${ }^{\circ} 4.502 / 64$ refere-se a atos praticados com a intenção de "impedir" ou "retardar" a ocorrência do fato gerador, todavia, só se impede ou se retarda algo que em esteja em curso, no caso, o fato gerador (Greco, 2011, p. 268); essa situação pode se exemplificada por uma empresa que emite a nota fiscal descrevendo nesta um produto diferente do efetivamente transportado para se aproveitar de uma alíquota menor do ICMS $^{10}$, nesta situação, temos um caso de fraude, pois, o intuito do contribuinte foi impedir ainda que parcialmente a ocorrência do fato gerador, fraudando o documento fiscal.

A breve análise dos conceitos citados é importante para se apurar quando o contribuinte esta na esfera da evasão e não da elisão tributária

\subsection{Evasão Tributária}

Barreto (2010, p. 272) dispõe que a: "evasão tributária, caracteriza-se pela conduta do contribuinte de, por meio ilícitos, assim qualificados na legislação tributária, (i) evitar a ocorrência do fato jurídico tributário; (ii) reduzir o montante devido a título de tributo; ou (iii) postergar a sua incidência”.

Germano (2013, p. 57) define evasão fiscal como: "conduta que enseja o não pagamento de tributos mediante a prática de atos diretamente contrários ao ordenamento".

10 Imposto sobre Circulação de Mercadorias e Prestações de Serviço de Transporte Intermunicipal e Interestadual e de Comunicação. 
Para Sillos (2005, p. 13): “por evasão fiscal entendem-se as práticas ilícitas adotas pelo contribuinte com o objetivo de evadir-se do cumprimento da obrigação tributária relacionada ao pagamento do tributo", nesse mesmo sentido também dispõe Melo (2007. p. 209): “a evasão situa-se em pólo aposto à elisão, que pode ser compreendida como toda ação (ou omissão) de natureza ilícita, minorando ou eliminando a obrigação tributária”, assim, analisando os conceitos postos, podemos compreender que a evasão tributária se caracteriza pela adoção de condutas ilícitas que visam diminuir ou excluir o crédito tributário.

Todavia, é importante mencionar que o conceito atribuído ao termo "evasão" não é absoluto, pois, há quem entenda, como Hugo de Brito Machado que a palavra evasão tem o sentido de "evitar" o tributo e portanto, seria mais adequada a sua utilização para designar as condutas lícitas. (Machado, 2014, p. 74-75).

Embora haja interpretações diferentes para o termo "evasão", vamos designar para os fins propostos no presente artigo, a evasão com sendo a adoção de condutas ilícitas para evadir-se do pagamento do tributo.

Neste contexto, podemos então enquadrar, a fraude, a simulação, o conluio, bem como a sonegação fiscal, pois, em ambas as situações, conforme análise empreendida no tópico 2.1 as condutas adotadas são revestidas de ilicitude uma vez que estão conectadas em impedir, retardar, ocultar/esconder, ou seja, ludibriar o fisco. Aspecto distinto se dá na elisão tributária ou fiscal.

\subsection{Elisão Tributária}

A Elisão tributária, ao contrário da evasão, é conceituada por diversos autores como sendo a adoção de condutas lícitas que visam eliminar ou reduzir o tributo. Nesse sentido dispõe Derzi (2007, p. 295): "Na elisão os meios são lícitos e o ato ou negócio jurídico é real, desencadeia efeitos próprios, não mascara a ocorrência do fato gerador e há compatibilidade entre a forma e o conteúdo".

Também assevera Lívio Sillos (2005. p.11): “a elisão fiscal qualifica-se como procedimento lícito realizado pelo contribuinte no escopo de reduzir a sua carga tributária".

Barreto $(2010,272)$ dispõe que a elisão: “consiste no direito subjetivo assegurado ao contribuinte de, por meios lícitos: (i) evitar a ocorrência do fato jurídico tributário; (ii) reduzir o montante devido a título de tributo; (iii) postergar a sua incidência".

Greco (2011, p. 15) em estudo aprofundado sobre o tema traz importante lição sobre o termo elisão e o chamado "Planejamento Tributário", dispondo que: “Planejamento' é a 
atividade exercida pelo contribuinte, enquanto 'elisão' é o efeito de submeter-se a uma menor carga tributária, obtida pelo planejamento", assim para o autor a elisão é o efeito de alcançar uma menor carga tributária pelo planejamento.

Embora não se possa deixar de destacar que há autores ${ }^{11}$ que entendem que a adoção de meios lícitos para reduzir a carga tributária deva receber outra denominação como “evasão" ou "elusão", adotaremos para o presente artigo, a expressão "elisão tributária" para designar a adoção de condutas lícitas com o objetivo de reduzir, postergar ou eliminar o tributo, realizada por meio de um planejamento.

Embora revestida de licitude, a utilização pelas empresas da elisão tributária por meio do chamado "planejamento tributário", têm sido objeto de questionamentos por parte da autoridade fazendária, pois, acabam por resultar em postergação, diminuição e até mesmo eliminação do tributo, o que aos olhos do fisco não é interessante, nem satisfatório.

Por isso, a questão que se coloca em discussão, é justamente saber quais são os mecanismos que autorizam a autoridade fazendária a desconsiderar atos praticados pela empresa que têm como objetivo reduzir a carga tributária; ou seja, em que medida a autoridade administrativa pode desconsiderar tais planejamentos?

\title{
3. A DESCONSIDERAÇÃO COMO CONSEQUÊNCIA DO PROCEDIMENTO FISCALIZAÇÃO
}

\subsection{Norma Geral Antielisão}

A Lei Complementar $\mathrm{n}^{\text {o }}$ 104, de 10 de Janeiro de 2001 (BRASIL, 2001), realizou diversas alterações no Código Tributário Nacional, entre as quais, incluiu o parágrafo único ao art. 116 que está inserido do Capítulo do "Fato Gerador", dispondo que:

\begin{abstract}
“A autoridade administrativa poderá desconsiderar atos ou negócios jurídicos praticados com a finalidade de dissimular a ocorrência do fato gerador do tributo ou a natureza dos elementos constitutivos da obrigação tributária, observados os procedimentos a serem estabelecidos em lei ordinária."
\end{abstract}

11 Nesse sentido podemos destacar o posicionamento de Hugo de Brito Machado e Livia de Carli Germano. 
A inclusão do parágrafo único ao art. 116 do Código Tributário Nacional causou e ainda causa diversos debates na doutrina, seja a respeito do seu propósito, seja em relação a sua aplicação diante de planejamentos tributários.

Barreto (2010, p. 273) efetuando importante análise sobre a alteração procedida dispõe que:

\begin{abstract}
"Até o advento da Lei Complementar no 104, de 2001, os limites estabelecidos para a atuação do contribuinte eram dolo, fraude e simulação. Se não fosse comprovada a existência de dolo, fraude ou simulação, os negócios jurídicos desenvolvidos pelo contribuinte não eram objeto de questionamento. Contudo, a partir da mudança no artigo 116 do Código Tributário Nacional, as restrições à estruturação de negócios jurídicos pelo contribuinte aumentam significativamente, notadamente em razão dos distintos enfoques interpretativos atribuídos ao comando normativo inserido no sistema jurídico brasileiro pela Lei Complementar no 104, de 2001."
\end{abstract}

Verifica-se então que a inserção do parágrafo único ao art. 116 do Código Tributário Nacional trouxe diversos questionamentos para dentro das estruturas até então adotadas pelos contribuintes. Esses questionamentos se dão pela própria descrição normativa do dispositivo, em especial a expressão "dissimular". O que o legislador quis dizer com a referida expressão? Seria o mesmo que simular?

Machado (2014, p. 62) ao tratar da dissimulação constante no parágrafo único do art. 116 do CTN dispõe que a expressão serve "para indicar a conduta com a qual o contribuinte praticaria um ato ou negócio jurídico tentando esconder a ocorrência do fato gerador do tributo". Para Barreto (2010, p. 274): “A dissimulação, espécie do gênero simulação, pressupõe a existência de dois fatos: o simulado, construído pelo contribuinte; e o que se pretendeu ocultar, a ser construído por aquele que deseja comprovar a simulação".

Analisando os respectivos autores verifica-se que a simulação e a dissimulação são dois fatos distintos, de tal forma que efetivamente o parágrafo único do art. 116, quis se referir a dissimulação e não a simulação.

Greco (2011, p. 548) ao analisar a inclusão do parágrafo único ao art. 116 do CTN dispôs que: "Seu único objetivo é autorizar que seja afastada a 'máscara' (a dissimulação), para permitir atingir o fato gerador que tenha efetivamente ocorrido (este é o termo utilizado pela norma do CTN = 'dissimular a ocorrência"”, todavia, a grande questão que se coloca é: 
quais são os meios que podem ser utilizados pela autoridade administrativa para desconsiderar os atos ou negócios jurídicos praticados com a finalidade de dissimular a ocorrência do fato gerador?

A parte final do parágrafo único do art. 116 do Código Tributário Nacional (BRASIL, 1966) dispõe: “observados os procedimentos a serem estabelecidos em lei ordinária”. Então quais seriam esses procedimentos?

Primeiramente é importante ressaltar que inexiste "Lei Ordinária" dispondo sobre procedimentos para desconsideração de atos considerados dissimulados.

Até tentou-se regular a matéria por meio da Medida Provisória 66/02 $2^{12}$, mas sem êxito.

A Medida Provisória ${ }^{\circ}$ 66, de 29 de Agosto de 2002 (BRASIL, 2002), trouxe uma parte denominada "Procedimentos relativos à Norma Geral Anti-Elisão", e dos arts. 13 a 19 tratou do assunto.

Logo no parágrafo único do art. 13, a Medida Provisória nº 66/02 tratou de esclarecer que as normas ali expostas não incluíam atos e negócios jurídicos praticados com dolo, fraude ou simulação; e assim, deixou claro ser a dissimulação algo distinto das figuras já tratadas pelo ordenamento jurídico.

Também tentou definir dissimulação, conforme se observa abaixo (BRASIL, Medida Provisória ${ }^{\circ}$ 66, de 2002):

“Art. 14. São passíveis de desconsideração os atos ou negócios jurídicos que visem a reduzir o valor de tributo, a evitar ou a postergar o seu pagamento ou a ocultar os verdadeiros aspectos do fato gerador ou a real natureza dos elementos constitutivos da obrigação tributária."

12 Dispõe sobre a não cumulatividade na cobrança da contribuição para os Programas de Integração Social (PIS) e de Formação do Patrimônio do Servidor Público (Pasep), nos casos que especifica; sobre os procedimentos para desconsideração de atos ou negócios jurídicos, para fins tributários; sobre o pagamento e o parcelamento de débitos tributários federais, a compensação de créditos fiscais, a declaração de inaptidão de inscrição de pessoas jurídicas, a legislação aduaneira, e dá outras providências. 
No $\S 1^{\circ}$ do art. 14 tentou fixar os critérios para a desconsideração, dispondo que seria levado em conta, entre outras, a ocorrência de falta de "propósito negocial" ou "abuso de forma", todavia, é importante ressaltar apenas para esclarecer o presente tópico, mas sem esgotar o assunto que será tratado na sequência, que tais dispositivos da Medida Provisória não foram tratados na Lei $\mathrm{n}^{\circ} 10.637$, de 30 de dezembro de 2002, que disciplinou os dispositivos constantes na medida.

Mesmo assim, esse dispositivo ficou conhecido como norma geral anti-elisão, no sentido, de o que o seu objetivo é efetivamente desconsiderar atos praticados pelo contribuinte com o intuito de diminuir a carga tributária, ainda que por meio lícitos, mas desprovidos de um propósito negocial ou extratributário.

\subsection{Propósito Negocial e Extratributário}

Segundo Machado (2014, p. 115): “Entende-se por 'propósito negocial' o que os americanos chamam business purpose - expressão com a qual designam o propósito ou motivação que ordinariamente está presente, porque enseja atividade empresarial"; no caminho contrário, mas tentando dar-lhe um conceito o $§ 2^{\circ}$ do art. 14 da Medida Provisória

66/02 (BRASIL, 2002) determinava que: "Considera-se indicativo de falta de propósito negocial a opção pela forma mais complexa ou mais onerosa, para os envolvidos, entre duas ou mais formas para a prática de determinado ato".

Assim para o referido dispositivo a adoção pela empresa de uma opção ou de uma operação mais complexa entre duas ou mais formas existentes já seria indicativo de falta de propósito negocial e, portanto, autorizaria a desconsideração; logo, tal dispositivo não pode prosperar: (i) uma porque traz um conceito diferente daquele denominado "business purpose" de base norte-americana que está conectado a adoção de procedimentos voltados para a atividade empresarial e não necessariamente tributária, embora esta possa ocorrer como consequência; (ii) nem sempre a forma mais simples é mais indicada para a empresa, pois, sabe-se que principalmente no campo dos tributos federais, a depender da atividade, a forma mais complexa é a mais indicada e às vezes obrigatória.

Todavia, ainda que superada a necessidade de um propósito negocial, há autores que defendem que para a validade do planejamento tributário é necessário que haja um motivo extratributário, ou seja, a redução, eliminação ou postergação do tributo não pode ser o único 
objetivo do planejamento adotado; é o que se depreende das considerações feitas por Greco (2011, p. 236): "o motivo que afasta o abuso é o extratributário, vale dizer, pode ser uma razão familiar, política, de mudança de regime jurídico das importações, de alteração do quadro referencial em que se posicionava a atividade da empresa etc.”.

A exigência de um motivo extratributário para evitar que seja desconsiderado o planejamento tributário é visto com críticas por Machado (2014, p. 116): "Não é razoável, portanto, entender que na escolha da forma de exercer suas atividades a empresa desconsidere o ônus da tributação" e arremata dispondo (2014, p. 118): "Realmente, o propósito de praticar uma atividade econômica com o menor custo possível, inclusive tributário, é indiscutivelmente legítimo".

Dá análise empreendia até este ponto, é possível depreender que até o presente momento não é possível a desconsideração de planejamentos praticados por meio da elisão fiscal, com base no parágrafo único do art. 116, eis, que ainda que tenha ocorrida a tentativa da sua implementação, esta não prosperou, conforme observa Barreto (2010, p. 282): "Carece de regulamentação tal procedimento, padecendo a norma veiculada pelo parágrafo único do art. 116 do Código Tributário Nacional de ineficácia técnica de natureza sintática”.

Assim, a pergunta que fica é: como os procedimentos ilícitos (evasão fiscal) adotados pelas empresas, por meio de fraude, dolo, simulação ou sonegação fiscal que objetivam a redução ou até mesmo extinção da carga tributária podem ser desconsiderados? Para essas situações, se faz necessário analisar outras normas, como por exemplo, a Lei nº 8.137/90 (que define os crimes contra à ordem tributária), mas que não será objeto de análise neste artigo; assim analisaremos à luz do Código Tributário Nacional o art. 149 que dispõe sobre o lançamento de ofício.

\subsection{Revisão de Ofício (Art. 149, Código Tributário Nacional)}

O art. 149 do Código Tributário Nacional (BRASIL, 1966) traz diversas hipóteses em que o lançamento é efetuado e revisto de ofício pela autoridade administrativa, entre os quais destacamos o inciso VII: "quando se comprove que o sujeito passivo, ou terceiro em benefício daquele, agiu com dolo, fraude ou simulação".

O lançamento de ofício segundo Leandro Paulsen (2014, p. 212):

"é aquele realizado direta e exclusivamente pelo fisco quando a lei assim o determine ou quando o tributo seja submetido por lei a uma das modalidades anteriores (mediante declaração ou por homologação), mas o contribuinte não tenha realizado os atos que lhe caibam, ou seja, não tenha prestado as informações ou apurado e pago o tributo devido. Neste caso, o 
lançamento de ofício terá caráter supletivo, será a única forma de o fisco obter a formalização do seu crédito tributário."

Também dispõe Carvalho (2009, p. 460), analisando a figura do lançamento de ofício: "Realmente, não teria sentido comprometer o curso regular da atividade de gestão tributária, protegendo omissões do administrado, nem sempre interessado na eficiência do procedimento controlador que o Poder Público deve exercer com relação às suas prerrogativas", assim, tem a autoridade administrativa por meio das disposições previstas no art. 149, em especial o inciso VII, objeto da referida análise, mecanismos para exigir o tributo que deixou de ser recolhido ou foi recolhido a menor, em virtude de fraude, dolo ou simulação.

Entretanto, o inciso VII do art. 149 não dispõe sobre a "dissimulação", expressão conhecida como simulação relativa, presente no parágrafo único do art. 116, nesse sentido dispõe Barreto (2010, p. 113): "Tratando-se de simulação relativa, isto é, de dissimulação, a norma aplicável é o parágrafo único do artigo 116 do mesmo diploma legal, cuja eficácia técnica (sintática) está condicionada à edição de lei ordinária"; importante observação também é feita por Greco (2011, p. 557): “somente estarão dependentes da regulamentação do dispositivo as hipóteses que não se enquadrem no artigo 149 do CTN".

Assim as situações trazidas à discussão em relação a ilícitos tributários, como fraude, dolo, simulação, são passíveis de serem desconsideradas independentemente do parágrafo único do art. 116 do CTN, tendo com fundamento o inciso VII do art. 149 do Código Tributário Nacional.

Entretanto, não atinge ao nosso ver, as situações de planejamento tributário praticados de maneira lícita que acabam resultando em diminuição, postergação ou extinção do tributo. Nesse sentido importante observação é feita por Machado (2014, p. 113):

\footnotetext{
"não temos dúvida de que evitar o planejamento tributário é atribuição do legislador. E até podemos afirmar que as definições da hipótese de incidência em geral, são atualmente, dotadas do propósito de afasta o planejamento tributário. Por isso mesmo temos imposto sobre circulação de mercadorias, e não um imposto cujo fato gerador seja a compra e venda mercantil". Temos imposto sobre transmissão de bens imóveis, e não imposto sobre compra e venda de imóveis - e assim por diante."
}

O que entendemos não ser cabível pelas análises realizadas, é admitir que a autoridade administrativa possa desconsiderar planejamentos tributários adotados de maneira lícita, ou seja dentro dos parâmetros de liberdade que a própria norma confere, com o intuito de diminuir a sua carga tributária, utilizando como fundamento o parágrafo único do art. o art. 116 do Código Tributário Nacional ou exigindo propósito não previstos. 
O art. 149 do Código Tributário Nacional já garante ao fisco a possibilidade de efetuar o lançamento de ofício nas situações em que fique comprovado que o contribuinte ou terceiro em benefício daquele, agiu com dolo, fraude ou simulação.

\section{CONSIDERAÇÕES FINAIS}

As análises empreendidas sobre o processo e o procedimento administrativo se mostraram relevante na medida em que nos permitiu, dentro do âmbito tributário e da linha proposta, efetuar uma separação simples e clara de ambos (processo e procedimento) e assim analisar com prudência os seus princípios.

Os contribuintes, assim como a Administração devem estar ciente dos seus direitos e obrigações e assim evitar desgastes desnecessários, que em nada contribuem para o bom desempenho de suas atividades.

O lançamento seja como "ato", seja como "procedimento" é importante instrumento que possui o Estado para garantir o seu crédito tributário. Por ser um ato vinculado, deve ser adstrito a legalidade objetiva, não podendo se valer de procedimentos que não previstos em lei, a fim de satisfazer sua pretensão arrecadatória, pois, deve lembrar que na outra ponta, esta o contribuinte, razão da sua própria existência, enquanto "Estado Democrático".

Assim como o Estado por meio do lançamento deve exigir o crédito tributário e utilizar todos os procedimentos dispostos em lei para fazê-lo, também o contribuinte diante da alta carga tributária que lhe é imposta diuturnamente, procurar mecanismos que visem diminuí-la ou até mesmo eliminá-la.

Esses mecanismos adotados pelos contribuintes podem se dar de forma lícita, que com base na pesquisa realizada, convencionamos chamar "elisão fiscal" ou de maneira ilícita, que com base na mesma análise convencionamos denominar "evasão fiscal”.

O tema do planejamento tributário se insere dentro do contexto da elisão fiscal, e por isso mesmo, dentro da esfera de liberdade do contribuinte que poderá adotar condutas que visem postergar, eliminar ou reduzir o seu tributo por meio de condutas lícitas, e portanto, permitidas; entretanto, a Administração não quer ficar a mercê de tais procedimentos e independentemente da licitude dos mesmos, promove diversas fiscalizações no sentido de averiguar a existência de alguma irregularidade. 
Tais procedimentos são válidos e refere-se ao próprio poder de fiscalizar que a autoridade administrativa possui, todavia, deve ser visto com cautela, pois, a sua execução só pode se dar nas situações legalmente previstas e desde que não seja desrespeitado nenhum direito e garantia do contribuinte.

O art. 149, VII, do Código Tributário Nacional, ora analisado, é um desses instrumentos legalmente previstos que autorizam a autoridade administrativa a efetuar o lançamento de ofício quando se comprove que o sujeito passivo, ou terceiro em benefício daquele, agiu com dolo, fraude ou simulação.

Entretanto, o respectivo inciso tratou de conceitos bem específicos: dolo, fraude e simulação.

Outro instrumento que é considerado como passível de utilização pela autoridade fazendária, é o parágrafo único do art. 116 também do Código Tributário Nacional, que autoriza a autoridade administrativa a desconsiderar atos praticados com a finalidade de dissimular o fato gerador, observados os procedimentos a serem previstos em lei ordinária.

Ora, ainda que o legislador tenha por objetivo, por meio da referida norma, desconsiderar atos praticados por meio da elisão fiscal, não nos parece que adotou a melhor terminologia e técnica. Primeiro, porque o termo "dissimulação" abriu um leque para se questionasse se efetivamente o legislador queria tratar da simulação ou de outra forma, a dissimulação, também conhecida como simulação relativa, e assim ampliou o campo de análise para desconsiderações por parte do fisco; segundo, porque esqueceu o legislador que a referida norma para ser aplicada necessita de uma lei ordinária, a definir os seus procedimentos.

Até tentou-se tratar da matéria por meio da Medida Provisória $n^{\circ} 66 / 02$, todavia, na sua conversão para a Lei $\mathrm{n}^{\circ} 10.637 / 02$, tais dispositivos não foram incorporados.

Diante deste cenário, pode-se concluir que a autoridade administrativa esta a depender da publicação de lei, lei ordinária, que lhe autorize a desconsiderar planejamentos adotados pela empresa por meio da elisão fiscal.

De outra parte, para as condutas ilícitas como o dolo, a fraude e a simulação, a autoridade administrativa já possui fundamentos para desconsiderá-los e assim exigir o respectivo tributo por meio do lançamento de ofício, tendo como base o inciso VII do art. 149 do Código Tributário Nacional.

Ressaltamos, em tempo, que nos parece adequado dispor que cabe ao legislador onde ocorrer situações que entenda existir certo grau de liberdade ao contribuinte que possibilite 
diminuir a carga tributária, utilizar o expediente que lhe é inerente, a edição de norma, norma essa que tenha efetividade e possa abarcar legalmente as operações pretendidas. 


\section{REFERÊNCIAS}

BARRETO. Paulo Ayres. Segurança jurídica no planejamento tributário. In: ROCHA. Valdir de Oliveira (Coord.). Grandes questões atuais do direito tributário. 14º vol. São Paulo: Dialética, 2010. p. 268-282.

BRASIL. Lei no 4.502, de 30 de Novembro de 1964. "Dispõe Sobre o Imposto de Consumo e reorganiza a Diretoria de Rendas Internas.". Disponível em < http://www.planalto.gov.br/ccivil_03/LEIS/L4502.htm> cesso em 24/07/15 às 15:00 hs.

BRASIL. Código Tributário Nacional, 1966. Disponível em <http://www.planalto.gov.br/ccivil_03/leis/L5172.htm> Acesso em 24/04/15.

BRASIL. Decreto $\mathbf{n}^{\circ} \mathbf{7 0 . 2 3 5}$, de 06 de Março de 1972. "Dispõe sobre o processo administrativo fiscal, e dá outras providências". Disponível em: $<$ http://www.planalto.gov.br/ccivil_03/decreto/d70235cons.htm> Acesso em 24/07/15 às 15:00 hs.

BRASIL. Constituição Federal da República Federativa do Brasil, 1988. Disponível em $<$ http://www.planalto.gov.br/ccivil_03/constituicao/constituicaocompilado.htm> Acesso em 24/04/15.

BRASIL. Lei $\mathbf{n}^{0}$ 9.784, de 29 de Janeiro de 1999. "Regula o processo administrativo no âmbito da Administração Pública Federal”. Disponível em $<$ http://www.planalto.gov.br/ccivil_03/LEIS/L9784.htm> cesso em 24/07/15 às 15:00 hs.

BRASIL. Lei Complementar $\mathbf{n}^{\mathbf{0}}$ 104, de Janeiro de 2001. Disponível em: <http://www.planalto.gov.br/ccivil_03/leis/LCP/Lcp104.htm> Acesso em 02/08/15 às 11:30 hs

BRASIL. Medida Provisória $\mathbf{n}^{\mathbf{0}}$ 66, de 29 de Agosto de 2002. Disponível em: $<$ http://www.planalto.gov.br/ccivil_03/mpv/Antigas_2002/66impressao.htm> Acesso em 02/08/15 às 11:30 hs

BRASIL. Código $\quad$ Civil, $2002 . \quad$ Disponível <http://www.planalto.gov.br/ccivil_03/leis/2002/L10406.htm> Acesso em 24/04/15.

CARVAlHO. Paulo de Barros. Curso de direito tributário. 21. ed. São Paulo: Saraiva, 2009.

DERZI. Misabel Abreu Machado. O direito à economia de imposto - seus limites (estudo de casos). In: YASMAHITA. Douglas (Coord.). Planejamento tributário à luz da jurisprudência. São Paulo: Lex Editora, 2007. p. 289-326

DI PIETRO. Maria Sylvia Zanella. Discricionariedade administrativa na Constituição de 1988. 2. ed. São Paulo: Atlas, 2001. 
GERMANO. Livia De Carli. Planejamento tributário e limites para a desconsideração dos negócios jurídicos. São Paulo: Saraiva, 2013.

GRECO. Marco Aurélio. Planejamento tributário. 3. ed. São Paulo: Dialética, 2011.

JUNIOR. José Cretella Júnior. Os cânones do direito administrativo. Revista de Informação Legislativa, v. 25, n. 97, p. 5-52, jan./mar. 1988. Disponível em $<$ http://www2.senado.leg.br/bdsf/item/id/181819>, p. 7.

MACEI. Demetrius Nichele. A verdade material no direito tributário: a cidadania fiscal administrativa e judicial. São Paulo: Malheiros, 2013.

MACHADO. Hugo de Brito. Introdução ao planejamento tributário. São Paulo: Malheiros, 2014.

MARINS. James. Direito processual tributário brasileiro: (administrativo e judicial). 5. ed. São Paulo: Dialética, 2010.

MELO. José Eduardo Soares de. Elisão e evasão de tributos: estudos de casos. In: YASMAHITA. Douglas (Coord.). Planejamento tributário à luz da jurisprudência. São Paulo: Lex Editora, 2007. p. 205-235

MELlO. Celso Antônio Bandeira de. Curso de direito administrativo. $26^{a}$ ed. São Paulo: Malheiros, 2009.

PAULSEN. Leandro. Curso de direito tributário: completo. 6 ed. Porto Alegre: Livraria do Advogado Editora, 2014.

RECEITA FEDERAL DO BRASIL. Carga Tributária no Brasil 2013. Disponível em $<$ http://idg.receita.fazenda.gov.br/dados/receitadata/estudos-e-tributarios-eaduaneiros/estudos-e-estatisticas/carga-tributaria-no-brasil/carga-tributaria2013.pdf> Acesso em 02/08/15 às 20:00 hs.

SILLOS. Lívio Augusto de. Planejamento tributário. São Paulo: Liv. e Ed. Universitária deDireito, 2005. 